\title{
Association between volume status as assessed by bioelectrical impedance analysis and echocardiographic parameters in peritoneal dialysis patients
}

\author{
(1) Duygu Ersan Demirci', (1) Deniz Demirci', (1) Melahat Çoban² \\ 1 University of Health Sciences Turkey, Antalya Training and Research Hospital, Clinic of Cardiology, Antalya, Turkey \\ 2Ankara City Hospital, Clinic of Nephrology, Ankara, Turkey
}

Date submitted:

19.12.2019

Date accepted:

27.04.2020

Online publication date:

15.09.2020

\section{Corresponding Author:}

Duygu Ersan Demirci, MD, University of Health Sciences Turkey, Antalya Training and Research Hospital, Clinic of Cardiology, Antalya, Turkey duygu_ersan@yahoo.com

ORCID:

orcid.org/0000-0003-2696-1531

Presented in: 34th Turkish Cardiology Congress with International Participation.

Keywords: Bioimpedance analysis, echocardiography, left ventricular mass index, peritoneal dialysis

\begin{abstract}
Aims: Fluid overload is one of the major problems causing severe complications in dialysis patients and the assessment of volume status is important for these patients. The aim of the study was to evaluate the relationship of fluid overload measured by bioimpedance analysis (BIA) with different echocardiographic parameters in peritoneal dialysis (PD) patients.

Methods: In this study, transthoracic echocardiography and BIA were performed on 35 PD patients. Patients were divided into two groups: overhydrated $(\mathrm{OH})(\mathrm{OH} \geq 1$.1) and non- $\mathrm{OH}<1.1$. This study assessed the differences in echocardiographic parameters between two groups and the association between BIA parameters and echocardiographic parameters including right heart indices.
\end{abstract}

Results: A total of 35 dialysis patients ( 21 males) were enrolled in the study. Based on $\mathrm{OH}, 21$ patients $(60 \%)$ with $\mathrm{OH} \geq 1.1$ (It) were considered $\mathrm{OH}$ and 14 patients (40\%) were considered non- $\mathrm{OH}$. There was no significant difference in respect to gender, age, hypertension, diabetes and dialysis vintage between two groups. Among the left heart echocardiographic parameters, left ventricular (LV) mass index (LVMI) was significantly higher in the $\mathrm{OH}$ group $(119.0 \pm 40.3$ vs. $239.4 \pm 37.4 \mathrm{~g} / \mathrm{m}^{2}, \mathrm{p}=0.046$ ). There was no significant difference with regard to other left and right ventricular echocardiographic parameters. Among various BIA parameters, we investigated $\mathrm{OH}, \mathrm{OH} /$ extracellular water $(\mathrm{ECW}), \mathrm{ECW} /$ total body water ratios and their correlations with echocardiographic parameters. We did not find any significant correlation between BIA parameters and echocardiographic findings.

Conclusions: The present study demonstrated the association between the hydration status and LVMI. We conclude that avoiding hypervolemia should be an important clinical goal in the follow-up of PD patients to prevent the progression of LV hypertrophy.

\section{Introduction}

The leading cause of morbidity and mortality for endstage renal disease patients is the cardiovascular diseases (1). Fluid overload is a common and serious problem leading to severe complications in hemodialysis (HD) and peritoneal dialysis (PD) patients. It is known that fluid overload is clearly associated with left ventricular (LV) hypertrophy, hypertension, and heart failure (2). The management of hypertension is difficult in dialysis patients and many patients have uncontrolled hypertension despite the use of antihypertensive drugs (3); hence, accurate control of the volume is one of the major targets of the therapy.

Hydration status can be measured by different methods. In routine evaluations, fluid management is largely based on subjective clinical assessment, such as blood pressure, edema and changes in body weight, but those may lead to misinterpretations. Therefore, more reliable, practical and objective methods are extremely needed. In this respect, bioelectrical impedance analysis (BIA) has been recommended for the assessment of hydration status parameters. 
BIA is a safe, easy, rapid and noninvasive method that has been used to evaluate hydration status in patients on dialysis therapy (4-7). Its working principal is associated with the human body's resistance to alternating electrical currents. It assesses hydration status, intracellular water (ICW) and extracellular water $(\mathrm{ECW})$, the extracellular and intracellular ratio, the total water volume and also some nutritional parameters (8). However, BIA is not available in many centers.

Transthoracic echocardiography is another method for the assessment of the volume status in dialysis patients. However, there are insufficient data on echocardiographic parameters indicating hydration status in patients undergoing dialysis. In the present study, we aimed to assess the relationship between hydration status measured with BIA technique and both left and right ventricular echocardiographic parameters in PD patients.

\section{Methods}

This cross-sectional study design included 35 (14 women, 21 men, mean age $52.2 \pm 14.1$ years) stable chronic ambulatory PD patients treated and followed up in the same center between November 2015 and February 2016. They were over 18 years of age and had been on PD therapy for at least 6 months. The study was approved by the Institutional Ethics Committee (Health Sciences University Turkey, Antalya Training and Research Hospital Ethics Committee 2013-022, 15/7, date: 28/02/2013) and informed consent was obtained from all patients at the time of study enrollment.

Five patients with a previously known severe valvulopathy, six patients who had LV systolic dysfunction with ejection fraction lower than $50 \%$, two patients with arrhythmia, two patients with contraindication for BIA (metallic prosthesis and pacemaker), one patient with previous renal transplantation and one patient with peritonitis were excluded from the study.

All patients were subjected to a thorough clinical evaluation. Blood samples were obtained in the morning after an overnight fasting, in the same day with BIA. Blood pressure, heart rate, clinical history, demographic characteristics, laboratory parameters and medication were recorded. Routine serum biochemical variables were analyzed. Body mass index (BMI) was calculated by dividing weight $(\mathrm{kg})$ by height square $\left(\mathrm{m}^{2}\right)$.

Residual renal function (RRF) was determined by residual glomerular filtration rate, residual diuresis and renal creatinine clearance. Residual glomerular filtration rate was measured as the average of 24-hour urinary urea and creatinine clearance values (9). Urine and dialysate samples were collected for 24 hours in order to calculate weekly total Kt/Vurea. Total Kt/ Vurea was determined as the total loss of urea nitrogen in the exchanged dialysate using the Watson equation (10). Peritoneal transport rates (PTR) were calculated by using standard peritoneal equilibration test as described by Twardowski et al. (11). According to the results, the patients were divided into four groups: high $(H)(\geq 0.81)$, high-average $(H A)(0.65-0.80)$, low-average (LA) $(0.50-0.65)$ and low $(L)(<0.50)$ PTR. $H$ and HA transporters were accepted as H-PTR, whereas L-LA transporters as L-PTR.

\section{Transthoracic Echocardiography}

Echocardiographic examinations were performed with a 2-4 $\mathrm{MHz}$ transducer attached to a Vivid S5 echocardiography machine (GE Healthcare, Chicago, USA). Single lead ECG was recorded continuously during the examination in left lateral decubitus position. Analysis was performed according to the guidelines of the American Society of Echocardiography recommendations $(12,13)$.

Three left atrium (LA) dimensions were used to calculate the LA volume as an ellipse using the following formula: LA volume $=(\pi / 6)(L A D 1 \times L A D 2 x L A D 3)$ where LAD1 is the anteroposterior LA dimension, and LAD2 and LAD3 are measurements of longand short axis with the apical four-chamber view at ventricular end-systole, respectively (14). To find LA volume index (LAVI) LA volume was divided by body surface area (BSA). BSA was calculated using the formula: $B S A=0.007184 x$ weight $0.425 x$ height $0.725\left(\mathrm{~m}^{2}\right)$. Interventricular septal thickness (IVST), posterior wall thickness (PWT), left ventricular end-diastolic diameter (LVEDD) and left ventricular end-systolic diameter (LVESD) were used to calculate LV mass (LVM) using the following equation: LVM $(g)=1.04 \times\left[(\text { LVEDD+IVST+PWT })^{3}-(\text { LVEDD })^{3}\right] \times 0.8+0.6$. LVM was divided by BSA to find LVM index (LVMI). Based on the studies of Devereux et al. (15), the cut-off values to define left ventricular hypertrophy (LVH) using the LVMI was $125 \mathrm{~g} / \mathrm{m}^{2}$ for both genders. To evaluate the diastolic functions of the LV, early mitral inflow velocity ( $E$ wave), late mitral inflow velocity (A wave) and deceleration time were evaluated from the apical 4-chamber view. The early diastolic velocity of the lateral mitral annulus (Em) was recorded with tissue Doppler imaging (TDI). To calculate E/ Em, E was divided by Em (16).

Right ventricular diameters were measured in the parasternal long axis and apical 4-chamber views. The maximal tricuspid regurgitation velocity was measured by continuous wave Doppler echocardiography from the apical 4-chamber view. Systolic pulmonary pressure was calculated as follows: 4X (tricuspid systolic jet) ${ }^{2}+$ right atrial pressure. Early (E) and late (A) right ventricular inflow velocities were measured with pulsed wave Doppler by placing the sample volume in between the tips of the tricuspid valve in the apical 4- chamber view. On the TDI images annular peak systolic velocity (Sa), early $(\mathrm{Ea})$ and late $(\mathrm{Aa})$ (peak annular diastolic velocities), tricuspid valve closure and opening time (TCO) and systolic velocity duration as ejection time (ET) were measured. The TDI-derived MPI, as a global estimate of both systolic and diastolic functions of the RV, was calculated with the formula 'TDI- MPI = (TCO-ET)/ET' (13). TAPSE was measured as placing an M-mode cursor through the tricuspid 
annulus and determining the amount of longitudinal motion of the annulus at peak systole in the apical 4- chamber view. Right ventricular fractional area change (RV FAC) was calculated using the formula ' $F A C=$ (end-diastolic area - end-systolic area) $/$ enddiastolic area x 100' (17).

\section{Bioimpedance Assessment}

Bioimpedance was assessed using a Body Composition Monitor (BCM, Fresenius Medical Care, Deutschland $\mathrm{GmbH}$ ). All measurements were obtained by the same operator. BIA was performed with empty abdomen in PD patients. The following parameters were obtained: overhydration $(\mathrm{OH}), \mathrm{ECW}, \mathrm{ICW}$, total body water (TBW) in liters (L), ECW/TBW, ECW/ICW ratios. These volumes then were used to evaluate the amount of fluid overload. $\mathrm{OH}$ is the difference between 'normal' ECW (the patient's expected ECW under normal physiologic conditions) and measured ECW and indicates 'absolute' volume overload. Relative fluid overload is defined as the absolute fluid overload to ECW ratio $(\mathrm{OH} / \mathrm{ECW})$. It is considered as an independent predictor of mortality in patients on dialysis when it is greater than $15 \%$ (18). We used $\mathrm{OH}$ (It) as an indicator of fluid status. Patients were classified by hydration status by means of $\mathrm{OH}$ normalized for healthy age and gender using the method described by Onofriescu et al. (19), that is -1.1 to $+1.1 \mathrm{~L}$, with volumes below and above this range, under- and over-hydration. Patients were divided into two groups: $\mathrm{OH} \geq 1.1$ and non- $\mathrm{OH}<1.1$.

\section{Statistical Analysis}

Data were processed using the MedCalc version 18.11.3 and $\mathrm{R}$ version 3.4.4. Mean and standard deviation or median and interquartile range were used for the presentation of measurable continuous quantitative variables, depending on the distribution of variables. For categorical data, frequencies and percentages were used. Suitability of parametric test conditions was checked for the comparison of quantitative variables (number of subjects and deviation from normal distribution). The Shapiro-Wilk test was used for normal distribution assessment. Two group comparisons were performed with the Student's t-test for variables that met parametric test conditions, and the Mann-Whitney $U$ test for others. The chi-square $\left(\chi^{2}\right)$ test and, if needed, the Fisher's exact test were used for the evaluation of categorical variables. Pearson's correlation coefficient was used to examine correlations between variables. Values of $p<0.05$ were considered statistically significant.

\section{Results}

\section{Patients' Characteristics}

A total of 35 dialysis patients (21 males) were enrolled in the study. Among the 35 patients included, the mean age was $52.2 \pm 14.1$ years. 27 patients $(77.1 \%)$ were hypertensive and nine patients $(25.7 \%)$ were diabetic with a mean dialysis vintage of $44.4 \pm 34.3$ months. Based on $\mathrm{OH}, 21$ patients $(60 \%)$

\begin{tabular}{|c|c|c|c|}
\hline & $\begin{array}{l}\mathrm{OH}<1.1 \\
(n=14)\end{array}$ & $\begin{array}{l}\mathrm{OH} \geq 1.1 \\
(n=21)\end{array}$ & $\mathbf{p}$ \\
\hline Gender (male) [n (\%)] & $10(71)$ & $10(52)$ & 0.409 \\
\hline Age (years) (mean $\pm S D)$ & $55.2 \pm 11.8$ & $49.9 \pm 15.7$ & 0.285 \\
\hline $\mathrm{DM}[\mathrm{n}(\%)]$ & $3(30.0)$ & $6(50.0)$ & 0.405 \\
\hline HT [n (\%)] & $9(64.3)$ & $18(94.7)$ & 0.062 \\
\hline $\mathrm{BMI}\left(\mathrm{kg} / \mathrm{m}^{2}\right)($ mean $\pm \mathrm{SD})$ & $27.47 \pm 5.3$ & $28.48 \pm 5.92$ & 0.611 \\
\hline Systolic BP (mmHg) (mean \pm SD) & $128.0 \pm 16.56$ & $131.05 \pm 19.11$ & 0.628 \\
\hline Diastolic BP $(\mathrm{mmHg})($ mean $\pm \mathrm{SD})$ & $78.0 \pm 12.07$ & $73.68 \pm 14.2$ & 0.355 \\
\hline ECW (L) $($ mean $\pm S D)$ & $16.8 \pm 2.57$ & $18.18 \pm 4.36$ & 0.371 \\
\hline ICW (L) (mean $\pm S D)$ & $19.62 \pm 3.99$ & $19.98 \pm 5.75$ & 0.877 \\
\hline TBW (L) (mean $\pm S D)$ & $35.02 \pm 6.18$ & $36.35 \pm 8.11$ & 0.547 \\
\hline Dialysis vintage (months) (mean $\pm \mathrm{SD})$ & $43.6 \pm 34.1$ & $45.4 \pm 35.74$ & 0.768 \\
\hline $\mathrm{Hgb}(\mathrm{g} / \mathrm{dL})(\operatorname{mean} \pm \mathrm{SD})$ & $10.3 \pm 3.3$ & $10.9 \pm 1.4$ & 0.402 \\
\hline Alb (g/dL) (mean $\pm S D)$ & $3.5 \pm 0.3$ & $3.4 \pm 0.5$ & 0.481 \\
\hline Cre $(\mathrm{mg} / \mathrm{dL})($ mean $\pm \mathrm{SD})$ & $7.4 \pm 3.1$ & $8.5 \pm 2.9$ & 0.255 \\
\hline $\mathrm{Ca}(\mathrm{mg} / \mathrm{dL})(\mathrm{mean} \pm \mathrm{SD})$ & $9.0 \pm 1.2$ & $9.0 \pm 0.65$ & 0.940 \\
\hline Ferritin $(\mathrm{ng} / \mathrm{mL})($ mean $\pm S D)$ & $318.2 \pm 230.2$ & $336.1 \pm 333.2$ & 0.861 \\
\hline $\mathrm{RRF}$ (mL/day) (mean $\pm \mathrm{SD})$ & $654.2 \pm 728.4$ & $906.7 \pm 654.2$ & 0.272 \\
\hline Weekly total Kt/Vurea (mean \pm SD) & $2.38 \pm 0.59$ & $2.41 \pm 0.54$ & 0.260 \\
\hline H-HA/L-LA PTRs [n (\%)] (mean \pm SD) & $13(92.8) / 1(7.2)$ & $17(80.9) / 4(19.1)$ & 0.858 \\
\hline
\end{tabular}


with $\mathrm{OH} \geq 1.1$ (It) were considered $\mathrm{OH}$ and 14 patients (40\%) were considered non-OH. Table 1 summarizes the general characteristics according to the volume status. There was no significant difference with respect to gender [10 (71\%) vs. 11 $(52 \%)$ male, $p=0.409]$, age $(55.2 \pm 11.8$ vs. $49.9 \pm 15.7, p=0.285)$, diabetes [6 (50\%) vs. $3(30 \%), p=0.405]$, systolic and diastolic blood pressure $(131.05 \pm 19.1$ vs. $128.0 \pm 16.56 \mathrm{mmHg}, p=0.628$; $73.68 \pm 14.2$ vs. $78.0 \pm 12.07 \mathrm{mmHg}, p=0.355$, respectively), BMI $\left(28.48 \pm 5.92\right.$ vs. $\left.27.47 \pm 5.3 \mathrm{~kg} / \mathrm{m}^{2}, p=0.611\right)$ and dialysis vintage $(45.4 \pm 35.74$ vs. $43.6 \pm 34.1$ months, $p=0.768)$ between the groups. The percentage of hypertension was higher in the $\mathrm{OH}$ group, but it was not statistically significant [18 (94.7\%) vs.
$9(64.3 \%), p=0.062]$. We found no significant difference with regard to biochemical parameters between two groups. We also demonstrated no significant difference in terms of RRF, Kt/ $\mathrm{V}$ and PTR values between the groups.

\section{Differences in Echocardiographic Parameters According to $\mathrm{OH}$}

Among the left heart echocardiographic parameters; IVST, PWT, thicknesses, LVEDD, LVESD, left ventricular outflow tract (LVOT) diameter, LA diameters and $\mathrm{E} / \mathrm{Em}$ were higher in the $\mathrm{OH}$ group, but none of them was found to be significant. However, LVMI was significantly higher in the $\mathrm{OH}$ group $(119.0 \pm 40.3$

\begin{tabular}{|c|c|c|c|}
\hline & $\mathrm{OH}<1.1$ & $\mathrm{OH} \geq 1.1$ & $p$ \\
\hline $\begin{array}{l}\text { LVMI }\left(\mathrm{g} / \mathrm{m}^{2}\right)(\operatorname{mean} \pm \mathrm{SD}) \\
\text { Median/min } / \mathrm{max}\end{array}$ & $\begin{array}{l}119.0 \pm 40.3 \\
105 / 76 / 208\end{array}$ & $\begin{array}{l}239.4 \pm 37.4 \\
124 / 98 / 227\end{array}$ & $0.046^{*}$ \\
\hline $\begin{array}{l}\text { IVST }(\mathrm{mm})(\operatorname{mean} \pm \mathrm{SD}) \\
\text { Median/min/max }\end{array}$ & $\begin{array}{l}12.8 \pm 2.2 \\
13 / 10 / 17\end{array}$ & $\begin{array}{l}12.9 \pm 1.9 \\
13 / 9 / 18\end{array}$ & 0.874 \\
\hline $\begin{array}{l}\text { PWT }(\mathrm{mm})(\operatorname{mean} \pm \mathrm{SD}) \\
\text { Median/min/max }\end{array}$ & $\begin{array}{l}11.7 \pm 1.4 \\
12 / 10 / 14\end{array}$ & $\begin{array}{l}12.6 \pm 1.6 \\
12 / 11 / 16\end{array}$ & 0.153 \\
\hline $\begin{array}{l}\text { LVEDD }(\mathrm{mm})(\operatorname{mean} \pm S D) \\
\text { Median/min/max }\end{array}$ & $\begin{array}{l}45.5 \pm 6.6 \\
45 / 36 / 58\end{array}$ & $\begin{array}{l}47.9 \pm 4.4 \\
47 / 41 / 60\end{array}$ & 0.915 \\
\hline $\begin{array}{l}\text { LVESD }(\mathrm{mm})(\text { mean } \pm S D) \\
\text { Median/min/max }\end{array}$ & $\begin{array}{l}29.9 \pm 6.3 \\
32 / 21 / 45\end{array}$ & $\begin{array}{l}30.6 \pm 5.0 \\
30 / 22 / 41\end{array}$ & 0.395 \\
\hline $\begin{array}{l}\text { LVOT }(\mathrm{mm})(\operatorname{mean} \pm \mathrm{SD}) \\
\text { Median/min/max }\end{array}$ & $\begin{array}{l}22.1 \pm 2.3 \\
22 / 18 / 26\end{array}$ & $\begin{array}{l}22.3 \pm 3.9 \\
22 / 16 / 35\end{array}$ & 0.911 \\
\hline $\begin{array}{l}\text { LAD D1 }(\mathrm{mm})(\operatorname{mean} \pm S D) \\
\text { Median } / \mathrm{min} / \mathrm{max}\end{array}$ & $\begin{array}{l}39.6 \pm 5.5 \\
39.0 / 15.9 / 36.2\end{array}$ & $\begin{array}{l}40.4 \pm 4.1 \\
40.5 / 31.0 / 47.0\end{array}$ & 0.619 \\
\hline $\begin{array}{l}\mathrm{LAVI}\left(\mathrm{mL} / \mathrm{m}^{2}\right)(\operatorname{mean} \pm \mathrm{SD}) \\
\text { Median } / \mathrm{min} / \mathrm{max}\end{array}$ & $\begin{array}{l}23.9 \pm 5.4 \\
24.2 / 15.9 / 36.2\end{array}$ & $\begin{array}{l}24.3 \pm 23.9 \\
24.8 / 17.9 / 40.9\end{array}$ & 0.884 \\
\hline $\begin{array}{l}\text { LV EF }(\%)(\operatorname{mean} \pm S D) \\
\text { Median/min/max }\end{array}$ & $\begin{array}{l}63.3 \pm 5.2 \\
65 / 55 / 65\end{array}$ & $\begin{array}{l}63.4 \pm 5.8 \\
65 / 55 / 65\end{array}$ & 0.521 \\
\hline
\end{tabular}

\section{Table 3. Left ventricular Doppler findings}

\begin{tabular}{llll} 
& $\mathrm{OH}<1.1$ & $\mathrm{OH} \geq 1.1$ & $\mathrm{p}$ \\
\hline $\mathrm{E}(\mathrm{m} / \mathrm{sn})(\mathrm{mean} \pm \mathrm{SD})$ & $0.68 \pm 0.2$ & $0.71 \pm 0.16$ & 0.631 \\
Median/min/max & $0.7 / 0.50 / 1.30$ & $0.70 / 0.40 / 1.0$ & \\
\hline $\mathrm{A}(\mathrm{m} / \mathrm{sn})(\mathrm{mean} \pm \mathrm{SD})$ & $0.9 \pm 0.13$ & $0.91 \pm 0.25$ & 0.879 \\
Median/min/max & $0.9 / 0.70 / 1.10$ & $0.90 / 0.11 / 1.20$ & \\
\hline Em $(\mathrm{cm} / \mathrm{sn})(\operatorname{mean} \pm \mathrm{SD})$ & $6.82 \pm 2.16$ & $6.95 \pm 2.77$ & 0.886 \\
Median/min/max & $7.00 / 3.00 / 12.00$ & $7.00 / 3.00 / 12.00$ & 0.735 \\
\hline Am $(\mathrm{cm} / \mathrm{sn})(\operatorname{mean} \pm \mathrm{SD})$ & $10.26 \pm 1.82$ & $9.9 \pm 3.42$ & \multirow{2}{*}{0.408} \\
Median/min/max & $10.0 / 7.0 / 13.0$ & $9.7 / 4.0 / 11.0$ & \multirow{2}{*}{0.134} \\
\hline E/Em $(\operatorname{mean} \pm \mathrm{SD})$ & $0.105 \pm 0.32$ & $0.122 \pm 0.07$ & \\
Median/min/max & $0.100 / 0.06 / 0.17$ & $0.100 / 0.04 / 0.33$ & $239.9 \pm 67.1$ \\
\hline DT $(\mathrm{mean} \pm \mathrm{SD})$ & $282.4 \pm 93.8$ & $262.0 / 54 / 348$ & \\
Median/min/max & $275.0 / 140.0 / 517.0$ & & \\
\hline A: Peak late diastolic mitral inflow velocity, Am: Late diastolic myocardial velocity, E: Peak early diastolic mitral inflow velocity, Em: Early diastolic myocardial velocity, \\
\hline DT: Deceleration time, OH: Overhydration, SD: Standard deviation, Min: Minimum, Max: Maximum
\end{tabular}




\begin{tabular}{|c|c|c|c|}
\hline & $\mathrm{OH}<1.1$ & $\mathrm{OH} \geq 1.1$ & $p$ \\
\hline $\begin{array}{l}\mathrm{RA} \text { area }\left(\mathrm{cm}^{2}\right)(\text { mean } \pm \mathrm{SD}) \\
\text { Median/min/max }\end{array}$ & $\begin{array}{l}20.9 \pm 24.4 \\
15.4 / 7.0 / 105.0\end{array}$ & $\begin{array}{l}13.2 \pm 3.3 \\
13.0 / 7.70 / 105.0\end{array}$ & 0.192 \\
\hline $\begin{array}{l}\text { RA long axis }(\mathrm{mm})(\text { mean } \pm S D) \\
\text { Median/min/max }\end{array}$ & $\begin{array}{l}44.8 \pm 5.50 \\
44.0 / 31.0 / 53.0\end{array}$ & $\begin{array}{l}45.6 \pm 6.03 \\
45.5 / 36.0 / 55.0\end{array}$ & 0.672 \\
\hline $\begin{array}{l}\text { RA minor axis }(\mathrm{mm})(\operatorname{mean} \pm \mathrm{SD}) \\
\text { Median } / \min / \max \end{array}$ & $\begin{array}{l}33.9 \pm 8.0 \\
34.0 / 14.0 / 45\end{array}$ & $\begin{array}{l}34.5 \pm 5.15 \\
34.5 / 28 / 46\end{array}$ & 0.484 \\
\hline $\begin{array}{l}\text { TAPSE }(\mathrm{mm})(\operatorname{mean} \pm S D) \\
\text { Median/min/max }\end{array}$ & $\begin{array}{l}23.3 \pm 5.2 \\
24 / 14 / 33\end{array}$ & $\begin{array}{l}22.03 \pm 3.9 \\
24 / 2 / 30\end{array}$ & 0.535 \\
\hline $\begin{array}{l}\text { RVFAC (\%) }(\text { mean } \pm \text { SD }) \\
\text { Median/min/max }\end{array}$ & $\begin{array}{l}42.72 \pm 17.86 \\
40.0 / 20.0 / 93.0\end{array}$ & $\begin{array}{l}39.6 \pm 9.32 \\
40.39 / 21.32 / 56.82\end{array}$ & 0.520 \\
\hline
\end{tabular}

\begin{tabular}{|c|c|c|c|}
\hline & $\mathrm{OH}<1.1$ & $\mathrm{OH} \geq 1.1$ & $p$ \\
\hline $\begin{array}{l}E(\mathrm{~m} / \mathrm{sn})(\mathrm{mean} \pm \mathrm{SD}) \\
\text { Median/min/max }\end{array}$ & $\begin{array}{l}0.60 \pm 0.11 \\
0.60 / 0.40 / 0.90\end{array}$ & $\begin{array}{l}0.62 \pm 0.17 \\
0.60 / 0.31 / 0.90\end{array}$ & 0.766 \\
\hline $\begin{array}{l}\mathrm{A}(\mathrm{m} / \mathrm{sn})(\mathrm{mean} \pm \mathrm{SD}) \\
\text { Median/min/max }\end{array}$ & $\begin{array}{l}0.58 \pm 0.14 \\
0.60 / 0.40 / 0.90\end{array}$ & $\begin{array}{l}0.63 \pm 0.17 \\
0.60 / 0.29 / 1.0\end{array}$ & 0.354 \\
\hline $\begin{array}{l}\text { Ea }(\mathrm{cm} / \mathrm{sn})(\operatorname{mean} \pm \mathrm{SD}) \\
\text { Median/min/max }\end{array}$ & $\begin{array}{l}11.0 \pm 4.3 \\
11.0 / 5.0 / 18.0\end{array}$ & $\begin{array}{l}11.45 \pm 3.27 \\
12.0 / 6.00 / 19.00\end{array}$ & 0.730 \\
\hline $\begin{array}{l}\mathrm{Aa}(\mathrm{cm} / \mathrm{sn})(\operatorname{mean} \pm \mathrm{SD}) \\
\text { Median/min/max }\end{array}$ & $\begin{array}{l}15.3 \pm 3.38 \\
16.0 / 7.0 / 19.0\end{array}$ & $\begin{array}{l}17.1 \pm 4.8 \\
17.0 / 11.0 / 26.0\end{array}$ & 0.234 \\
\hline $\begin{array}{l}\mathrm{E} / \mathrm{A}(\mathrm{mean} \pm \mathrm{SD}) \\
\text { Median/min/max }\end{array}$ & $\begin{array}{l}1.08 \pm 0.32 \\
1.16 / 0.63 / 1.75\end{array}$ & $\begin{array}{l}1.03 \pm 0.83 \\
0.66 / 0.09 / 1.10\end{array}$ & 0.661 \\
\hline $\begin{array}{l}\mathrm{Sa}(\mathrm{cm} / \mathrm{sn})(\operatorname{mean} \pm \mathrm{SD}) \\
\text { Median/min/max }\end{array}$ & $\begin{array}{l}17.75 \pm 3.38 \\
16.0 / 7.0 / 19.0\end{array}$ & $\begin{array}{l}14.0 \pm 4.43 \\
14.0 / 5.0 / 22.0\end{array}$ & 0.140 \\
\hline $\begin{array}{l}\text { Tr vel }(\mathrm{cm} / \mathrm{sn})(\operatorname{mean} \pm \mathrm{SD}) \\
\text { Median/min/max }\end{array}$ & $\begin{array}{l}2.27 \pm 0.61 \\
2.50 / 1.30 / 3.10\end{array}$ & $\begin{array}{l}2.12 \pm 0.58 \\
2.3 / 1.0 / 2.90\end{array}$ & 0.521 \\
\hline $\begin{array}{l}\text { Lateral TDI MPI (mean) (SD) } \\
\text { Median/min/max }\end{array}$ & $\begin{array}{l}0.27 \pm 0.13 \\
0.24 / 0.11 / 0.49\end{array}$ & $\begin{array}{l}0.24 \pm 0.13 \\
0.19 / 0.11 / 0.49\end{array}$ & 0.122 \\
\hline $\begin{array}{l}\text { PVR (dyn*sn/cm²) (mean) (SD) } \\
\text { Median/min/max }\end{array}$ & $\begin{array}{l}1.28 \pm 0.56 \\
1.33 / 0.16 / 2.16\end{array}$ & $\begin{array}{l}0.99 \pm 0.47 \\
1.12 / 0.61 / 1.66\end{array}$ & 0.540 \\
\hline
\end{tabular}

vs. $\left.239.4 \pm 37.4 \mathrm{~g} / \mathrm{m}^{2}, \mathrm{p}=0.046\right)$. Other LV echocardiographic parameters were similar in both groups (Table 2, 3). Among the right heart echocardiographic parameters, there was no significant difference between two groups (Table 4, 5).

\section{Correlation Between Echocardiographic Parameters and Markers of Volume Status}

Among various BIA parameters, we investigated $\mathrm{OH}$, $\mathrm{OH} / \mathrm{ECW}$, ECW/TBW ratios and their correlations with echocardiographic parameters. No significant correlation between BIA parameters and echocardiographic findings was found. We also did not find any significant correlation between RRF and echocardiographic parameters.

\section{Discussion}

In the present study, the relationship between hydration status measured with BIA and echocardiographic parameters was assessed. In the patients from a single center, we found that LVMI was related to hydration status based on $\mathrm{OH}(\mathrm{L})$.

Fluid overload is frequently present in dialysis patients leading to adverse clinical outcomes such as hypertension (20), cardiovascular diseases $(21,22)$ and higher mortality $(23)$; thus, keeping dialysis patients euvolemic is essential (24). Managing fluid balance is still major challenge in both HD and PD patients. Based on many studies, BIA is recommended for determining the dry weight $(25,26)$. In a study of Hur et al. $(27)$ regarding 
HD patients, assessment of fluid overload with BIA methods has been reported to be associated with better management of fluid status and regression of LVMI. However, access to BIA is limited in many centers leading determination of the volume status of patients only by clinical methods. Hur et al. (28), in a study including $81 \mathrm{PD}$ and $89 \mathrm{HD}$ patients, observed that $\mathrm{OH} /$ ECW ratio was positively correlated with LAVI. Di Gioia et al. (29), found that LAVI was related to hydration status based on bioimpedance measured time-averaged fluid overload. LAVI is a chronic marker of diastolic dysfunction that shows the average of increased filling pressures. In the present study, we did not find an association between hydration status and LAVI. In a study including $30 \mathrm{HD}$ patients, Sabaghian et al. (30), found a significant correlation between inferior vena cava diameter index minimum (IVCDi min) measured by echocardiography and ECW, so they suggested this parameter as a good echocardiographic parameter associated with hydration in HD patients.

Another study by Yılmaz et al. (31) reported that increased $\mathrm{OH} / \mathrm{ECW}$ ratio was independently associated with LVMI. Increased LVMI is associated with mortality and cardiovascular morbidity in this patient population (32). Despite the fact that several other factors play roles in the development of LV hypertrophy, the main causes are hypertension and fluid overload. Consistent with the previous reports, $\mathrm{OH}$ patients had significantly higher levels of LVMI compared to non-OH patients in our study. These findings emphasize the importance of volume control for cardiac protection in PD patients. Different from previous studies, we also investigated the association between right heart echocardiographic indices and BIA parameters, but we did not demonstrate any significant correlations. This can be due to the small sample size of our study and should be evaluated in larger scale studies.

Our study has several limitations. The most important limitation is that it included a small number of patients from a single center. We assessed right ventricular function with conventional echocardiography instead of strain echocardiography.

\section{Conclusion}

The present study demonstrated the association between the hydration status and LVMI. We conclude that avoiding hypervolemia should be an important clinical goal in the followup of PD patients in order to prevent the progression of LV hypertrophy. These results should be confirmed by further larger studies.

\section{Ethics}

Ethics Committee Approval: The study was approved by the Institutional Ethics Committee (Health Sciences University Turkey, Antalya Training and Research Hospital Ethics Committee 2013-022, 15/7, date: 28/02/2013).
Informed Consent: Informed consent was obtained from all patients at the time of study enrollment.

Peer-review: Externally peer-reviewed.

\section{Authorship Contributions}

Concept: D.E.D., D.D., M.Ç., Design: D.E.D., D.D., M.Ç., Data Collection or Processing: D.E.D., M.Ç., Analysis or Interpretation: D.E.D., D.D., Literature Search: D.E.D., D.D., Writing: D.E.D., D.D.

Conflict of Interest: No conflict of interest was declared by the authors.

Financial Disclosure: The authors declared that this study received no financial support.

\section{References}

1. London GM, Marchais SJ, Metivier F, Guerin AP. Cardiovascular risk in end-stage renal disease: vascular aspects. Nephrol Dial Transplant. 2000;15:97-104.

2. Tonelli M, Wiebe N, Culleton B, et al. Chronic kidney disease and mortality risk: a systematic review. J Am Soc Nephrol. 2006;17:2034-2047.

3. Koc M, Toprak A, Tezcan H, Bihorac A, Akoglu E, Ozener IC. Uncontrolled hypertension due to volume overload contributes to higher left ventricular mass index in CAPD patients. Nephrol Dial Transplant. 2002;17:1661-1666.

4. Wabel P, Chamney P, MoissI U, Jirka T. Importance of wholebody bioimpedance spectroscopy for the management of fluid balance. Blood Purif. 2009;27:75-80.

5. MoissI UM, Wabel P, Chamney PW, et al. Body fluid volume determination via body composition spectroscopy in health and disease. Physiol Meas. 2006;27:921-933.

6. Crepaldi C, Soni S, Chionh CY, Wabel P, Cruz DN, Ronco C. Application of body composition monitoring to peritoneal dialysis patients. Contrib Nephrol. 2009;163:1-6.

7. Wizemann V, Rode C, Wabel P. Whole-body spectroscopy $(\mathrm{BCM})$ in the assessment of normovolemia in hemodialysis patients. Contrib Nephrol. 2008;161:115-118.

8. Xu Y, Chen Y, Li D, et al. Hypertension, fluid overload and micro inflammation are associated with left ventricular hypertrophy in maintenance hemodialysis patients. Ren Fail. 2013;35:1204-1209.

9. Van Olden RW, Krediet RT, Struijk DG, Arisz L. Measurement of residual renal function in patients treated with continuous peritoneal dialysis. J Am Soc Nephrol. 1996;7:745-748.

10. Floré KM, Delanghe JR. Analytical interferences in pointofcare testing glucometers by icodextrin and its metabolites: an overview. Perit Dial Int. 2009;29:377-383.

11. Twardowski ZJ, Nolph KD, Prowant B, Ryan L, Moore H, Nielsen MP. Peritoneal equilibration test. Perit Dial Bull. 1987;7:138-147.

12. Lang RM, Badano LP, Mor-Avi V, et al. Recommendations for cardiac chamber quantification by echocardiography 
in adults: an update from the American Society of Echocardiography and the European Association of Cardiovascular Imaging. J Am Soc Echocardiogr. 2015;28:1-39.

13. Rudski LG, Lai WW, Afilalo J, et al. Guidelines for the echocardiographic assessment of the right heart in adults: a report from the American Society of Echocardiography endorsed by the EuropeanAssociation of Echocardiography, a registered branch of the European Society of Cardiology, and the Canadian Society of Echocardiography. J Am Soc Echocardiogr. 2010;23:685-713.

14. Lang RM, Bierig M, Devereux RB, et al. Recommendations for chamber quantification: a report from the American Society of Echocardiography's Guidelines and Standards Committee and the Chamber Quantification Writing Group, developed in conjunction with the European Association of Echocardiography, a branch of the European Society of Cardiology. J Am Soc Echocardiogr. 2005;18:1440-1463.

15. Devereux RB, Lutas EM, Casale PN, et al. Standardization of M-mode echocardiographic left ventricular anatomic measurements. J Am Coll Cardiol. 1984;4:1222-1230.

16. Wang AY, Wang M, Lam CWK, Chan IHS, Zhang Y, Sanderson JE. Left ventricular filling pressure by Doppler echocardiography in patients with end-stage renal disease. Hypertension. 2008;52:107-114.

17. Anavekar NS, Skali H, Bourgoun M, et al. Usefulness of right ventricular fractional area change to predict death, heart failure, and stroke following myocardial infarction (from the VALIANT ECHO Study). Am J Cardiol. 2008;101:607-612.

18. Wizemann $\mathrm{V}$, Wabel $\mathrm{P}$, Chamney $\mathrm{P}$, et al. The mortality risk of overhydration in haemodialysis patients. Nephrol Dial Transplant. 2009;24:1574-1579.

19. Onofriescu M, Hogas S, Voroneanu L, et al. BioimpedanceGuided Fluid Management in Maintenance Hemodialysis: A Pilot Randomized Controlled Trial. Am J Kidney Dis. 2014;64:111-118.

20. Fagugli RM, Pasini P, Quintaliani G, et al. Association between extracellular water, left ventricular mass and hypertension in hemodialysis patients. Nephrol Dial Transplant. 2003;18:2332-2338.

21. Enia G, Mallamaci F, Benedetto FA, et al. Long-term CAPD patients are volume expanded and display more severe left ventricular hypertrophy than hemodialysis patients. Nephrol Dial Transplant. 2001;16:1459-1464.
22. Konings CJAM, Kooman JP, Schonck M, et al. Fluid status, blood pressure, and cardiovascular abnormalities in patients on peritoneal dialysis. Perit Dial Int. 2002;22:477487.

23. Antlanger $\mathrm{M}$, Hecking $\mathrm{M}$, Haidinger $\mathrm{M}$, et al. Fluid overload in hemodialysis patients: a cross-sectional study to determine its association with cardiac biomarkers and nutritional status. BMC Nephrol. 2013;14:266.

24. Devolder I, Verleysen A, Vijt D, Vanholder R, Van Biesen $\mathrm{W}$. Body composition, hydration, and related parameters in hemodialysis versus peritoneal dialysis patients. Perit Dial Int. 2010;30:208-214.

25. Zhu F, Wystrychowski G, Kitzer T, Thijssen S, Kotanko $P$, Levin NW. Application of bioimpedance techniques to peritoneal dialysis. Contrib Nephrol. 2006;150:119-128.

26. Devolder I, Verleysen A, Vijt D, Vanholder R, Van Bielsen W. Body composition, hydration, and related parameters in hemodialysis versus peritoneal dialysis patients. Perit Dial Int. 2010;30:208-214.

27. Hur E, Usta M, Toz $\mathrm{H}$, et al. Effect of fluid management guided by bioimpedance spectroscopy on cardiovascular parameters in hemodialysis patients: a randomized controlled trial. Am J Kidney Dis. 2013;61:957-965.

28. Hur E, Yildiz G, Budak Köse S, et al. Bioimpedance and echocardiography used interchangeably in volume comparison of dialysis patients. Hippokratia. 2012;16:329334.

29. Di Gioia MC, Gascuena R, Gallar P, et al. Echocardiographic findings in hemodialysis patients according to their state of hydration. Nefrologia. 2017;37:47-53.

30. Sabaghian T, Hajibaratali B, Samavat S. Which echocardiographic parameter is a better marker of volume status in hemodialysis patients? Renal Fail. 2016;38:16591664.

31. Yılmaz Z, Yıldırım Y, YılmazAydın F, et al. Evaluation of fluid status related parameters in hemodialysis and peritoneal dialysis patients: Clinical usefulness of bioimpedance analysis. Medicina (Kaunas). 2014;50:269-274.

32. Chan CT, Greene T, Chertow GM, et al. Determinants of left ventricular mass in patients on hemodialysis: Frequent Hemodialysis Network (FHN) Trials. Circ Cardiovasc Imaging. 2012;5:251-261. 